\title{
MULTIPARTY DEMOCRACY AND ELECTIONS IN NAMIBIA
}

\author{
$B y$ \\ Debie LeBeau *
}

Dr Debie LeBeau is Senior Research Associate, University of Namibia PO Box 25193 Windhoek, Namibia 9000

Tel: +26461 248483

email: lebeau@mweb.com.na

\begin{abstract}
This paper examines the most recent round of elections in Namibia - those held in 2004. For those elections the Electoral Commission of Namibia (ECN) succeeded in reregistering almost one million voters, conducting by-elections, administering local, regional, national and presidential elections, as well as providing voter education at national and grassroots community levels. Of course the ECN did not complete these endeavours alone: the democratic process in Namibia is a cooperative (and sometimes competitive) effort between government, donors, non-governmental organisations (NGOs), civil society and political parties. In 200411 political parties were registered with the ECN - a high number for a country with only 977742 registered voters. The major issues in the 2004 election were economic growth, poverty, unemployment, land reform, agriculture, infrastructure, the eradication of corruption, education, health care, social welfare, gender equality, good governance, moral values and HIV/AIDS. With all parties focusing on the same issues and in the absence of viable policy alternatives, ethnicity, liberation struggle credentials and individual personalities within and between parties play a role in voting decisions.
\end{abstract}

* Acknowledgements: Meme Fransina Ndateelela Kahungu helped collect data from various NGOs, donors and governmental organisations. Edith Dima drafted sections of the original publication upon which this article is based. The author would like to extend a special thanks to Christiaan Keulder of the Institute for Public Policy Research (IPPR) who provided us with transcripts from interviews and data on the elections. However, most importantly, Christie devoted much time and attention to critically reviewing this paper, and to many discussions about theories and concepts relating to the consolidation of democracy - how extraordinary to find someone with such depth of knowledge who is so readily willing to share.

** An American by birth, Dr LeBeau has been living and working in Namibia for the past 15 years. She obtained her PhD from Rhodes University, South Africa. She is currently a senior researcher in the Gender Training and Research Programme at the University of Namibia and taught for eight years in the Department of Sociology. She has authored many books and chapters in books on Namibian issues. Her most recent co-authored book, with Eunice Iipinge, is the SADC publication Beyond Inequalities: Women in Namibia. Much of her work has focused on gender issues and HIV/ AIDS-related topics. 


\section{INTRODUCTION}

In line with international trends, the most recent figures on voter turnout show that turnout for local authority $(45 \%)$ and regional council elections $(53,5 \%)$ in Namibia were lower than that for the National Assembly and presidential elections $(85 \%)$. This apathy is disconcerting given that most people in Namibia have only had the vote for 15 years.

In any given society conflict surrounds power and political decision-making. Democracy, by its very nature, entails a certain level of development built through conflict. There are still some contested domains within the area of the electoral system itself, including those relating to the use of party lists and the Proportional Representation (PR) system. The 50/50 campaign which advocated 'zebra'-style lists, alternating women and men candidates for all elections so that half of the candidates put forward are women, was rejected on a technicality by a parliamentary standing committee.

Two significant conflicts centred on power sharing arose within political parties in the run-up to the 2004 elections. The first related to the ruling South West African People's Organisation Party's (SWAPO) selection of a new candidate for president, the other resulted in a split within the Democratic Turnhalle Alliance (DTA). In the run-up to the 2004 elections and during the post-election manoeuvring points of contention arose between political parties. In general these issues related to opposition parties confusing the government with SWAPO. When irregularities occurred during the process, political parties tended to attribute these to SWAPO rather than to government officials. The vast majority of election-related complaints centred on the mechanics of voting and the Electoral Commission of Namibia (ECN), although several members of opposition parties were not satisfied with the voting process and some opposition parties contested the 2004 presidential and National Assembly election results, winning the right to have the count verified by an independent auditing body.

In mid-March 2005 the court found that there had not been enough irregularities in the election process to warrant the outcome being set aside but that there had been sufficient irregularities in the counting process to order the ECN (not an external body) to recount the votes. The recount was only slightly different from the original count, with no change in the overall outcome. Although there were some alleged instances of political parties inciting their members to violence against opposition party members, probably the most common form of political violence was occasioned by members of opposing parties getting carried away with election fever. There was no evidence that the parties themselves had orchestrated the attacks.

One area in which it was hoped that political status might shift was in the domain of women's representation at the various levels of political decision-making. This was, however, not the case after the 2004 elections. Although women scored an early victory, with 43,4 per cent representation at local levels of government, 
they did not fare as well in the National Assembly and Regional Council elections where women's representation increased by less than 1 per cent, from 26,4 per cent to 27,3 per cent.

Probably one of the most significant contributions to the consolidation of democracy in Namibia is the ESC, a collaborative body consisting of donor organisations, NGOs and government. It is through such collaborative efforts that democracy can be consolidated in Namibia.

Bilateral donors, NGOs and civil society contribute in other ways to the democratic process in Namibia. Many of them work directly on issues relating to democracy, while others strive to develop the social, economic and educational lives of Namibians. Namibia is still a country with serious political and ethnic divides, as well as a general lack of understanding and acceptance of democracy: factors that could be a potentially serious obstacle to democratic consolidation. However, there are also positive attributes such as the country's high literacy rates, good levels of trust in representatives and a strong belief that the process is responsive to the needs of the people - all of which are conducive to the consolidation of democracy.

It seems that to continue to consolidate democracy Namibia will have to face voter apathy, rising rates of tolerance for other forms of government and plummeting voter confidence in the very officials the voters have elected. Probably one of the best ways of consolidating democracy is through civic and voter education, which should not be viewed as being necessary only at election time but should be an ongoing process that reinforces citizens' as well as politicians' demands for democracy.

\section{BACKGROUND}

At independence Namibia adopted a Constitution as the fundamental law of the country. The Constitution characterises the country as a republic, that is, 'a sovereign, secular, democratic and unitary State founded upon the principles of democracy, the rule of law and justice for all'. It further states that: 'All power shall be vested in the people of Namibia who shall exercise their sovereignty through the democratic institutions of the State' (GRN 1990, Ch 1 Art 1). To date there has been one amendment to the Namibian Constitution: in 1999 article 29(3) was amended to allow President Sam Nujoma to run for a third term of office.

The President is elected by 'direct, universal and equal suffrage and can serve for a maximum of two five-year terms' (GRN 1990, Ch 5 Arts 27/28). Presidential elections are based on a simple majority, whereby the candidate with the most votes wins provided that candidate has more than 50 per cent support (Hopwood 2004 , p 28). If no candidate receives a 50 per cent majority, further balloting will be held until one candidate does so (Hopwood 2004, p 30).

The legislature consists of the National Assembly with 72 members elected for a five-year term, as well as six non-voting members who are appointed by the 
President. The National Assembly is vested with the power to pass laws based on a two-thirds majority vote. A proportional electoral system is used to elect members of local authorities and the National Assembly (LeBeau \& Iipinge 2004, p 80). In the PR system political parties put out a closed list of candidates, with party leaders determining the order of names on the list. Voters do not vote for individual candidates but for the party of their choice and each party receives a percentage of seats equal to the percentage of votes received (GRN 2003). ${ }^{1}$ The PR system benefits small parties - many of which are ethnically based - because seats are divided according to the proportion of votes, making it possible for small parties to gain a seat even if they have not won a full quota of votes (Hopwood 2004, p 29).

The National Council is made up of two representatives drawn from each of the 13 geographical regions of the country who are elected for a six-year term from among the various regional council members (GRN 1990, Chapter 7). The plurality (first-past-the-post-FPTP) electoral system is used to elect members of the regional councils and indirectly to elect National Council representatives (GRN 1992). In this system, political parties put up individual candidates to be elected in designated constituencies.

\section{ELECTION AdMinistration}

Namibia, like most Southern African Development Community (SADC) countries, has an independent election management body, the Electoral Commission of Namibia. The ECN is guided by the Electoral Act 24 of 1992 and is responsible for the registration of voters and of political parties, as well as for supervising, directing and controlling elections (GRN 1992, Article 13). The ECN is tasked with informing all citizens 18 years and older of their democratic rights, as well as registering them to vote (EISA 2004, p 22). The ECN also oversees civic and voter education even though this task is not mandated by any electoral act; this responsibility falls within the SADC principles for electoral bodies (EISA 2004, p 22).

The law requires the ECN to re-register all eligible voters on a general voters' roll or voters' registration roll for regional, national and presidential elections every 10 years as well as to declare occasional supplementary registration periods. In addition the ECN must keep a voters' registration roll for local authority elections. This means that the commission was required to re-register almost a million voters. On the whole, the 2004 ECN voter registration exercise was completed satisfactorily,

1 Electoral Amendment Act No 7 of 2003. Namibia's version of PR is calculated by dividing the total number of votes cast by the number of seats so that each seat is represented by a specific number of votes cast (the 'quota of votes' per seat). The number of votes cast for a party is divided by the 'quota of votes' for each seat to determine how many seats each political party is awarded. Because the number of votes received by each party does not necessarily divide exactly into the quotas some seats remain unallocated. These unallocated seats are then allocated to parties with the largest number of votes remaining, even though that number may not have been enough to fulfil the 'quota of votes' for an extra seat (Hopwood 2004, p 29). 
an achievement helped by the acquisition of modern equipment. The ECN estimated that between 85 and 90 per cent of those eligible were registered to vote and political party representatives expressed general satisfaction with the process (Pitkanen 2004, p 6). Although there are inconsistencies in the general voters' roll, the proportion of these errors compared to the volume of the list (over 900000 people) is probably insignificant. In addition, the enormity of the task - to register all eligible voters nationwide with a total population density of 2,1 persons per $\mathrm{km}^{2}$ (2001 Census) attests to the ECN's overall success rather than to its few failures.

The ECN is part of a larger Electoral Support Consortium (ESC) funded by international donors and consisting of the government, in the form of the ECN, and several NGOs. The ESC was established to encourage voters to participate in elections and to help them make informed voting decisions (Somach et al 2004, $\mathrm{p} 1$ ). The ESC is unique in that it brings together international donor agencies, the government (through the ECN) and civil society (through the LAC, NID, IPPR and secondary partners) (Somach et al 2004, p 1). ${ }^{2}$

The ECN, as part of the ESC, provides a civic and voter education programme and focuses on creating voter awareness and ensuring the active participation of community members in the democratic process. Although the election laws do not specifically task the ECN with civic and voter education, given Namibia's history of disenfranchisement of the majority of the population, the ECN has determined that civic and voter education is essential for creating public awareness about the political process as well as for educating voters about how to participate in this process - especially in the light of the rising tide of voter apathy (ECN 2004, p 15).

The ECN began its voter education programme in 1992 and established a Democracy Building Unit (DBU) in 2001, which is responsible for civic and voter education as well as for the dissemination of electoral information (ECN 2004, p 15). In an effort to promote civic and voter education, the DBU has trained one regional voter educational officer for each of the country's 13 administrative regions. ${ }^{3}$ The work of these officers is to organise regional training workshops and meetings and to assist in the dissemination of voter education material produced by the DBU. The DBU also promotes voter education materials through national radio and television programmes (ECN 2004, p 15).

2 Funding partners include the governments of the Netherlands and Sweden as well as the United States Agency for International Development (USAID). Implementing partners include the ECN (which coordinates the overall programme), the Namibia Institute for Democracy (NID), the Legal Assistance Centre (LAC), and the IPPR. Recently a secondary consortium of partners was added to the Civic and Voter Education programme, namely, the Namibian School Debating Association, the Service Centre for the Visually Impaired, and the Namibia Community Radio Network. In addition, Sister Namibia although not a formal ESC or secondary consortium partner - also runs civic and voter education activities focusing on improving gender equality in political participation.

3 Pitkanen (2004, p 5) notes that this title is misleading because these officers also provide civic education. 


\section{The Political Parties in 2004}

In 200411 political parties were registered with the ECN (Hopwood 2004, p 43). Such large number of parties in a voting population of only 977742 is high. One possible explanation for this is the desire of individuals for power. In addition, the ethnic base of most parties promotes a tendency among them to view the country's leadership as being under the control of a particular ethnic group - this factor can negate democratic growth. Table 1 shows the number of seats won by political parties in the 2004 elections.

Table 1

Political party representation in the 2004 elections

\begin{tabular}{|c|c|c|c|}
\hline Party & National Assembly & Regional Council & Local Authority \\
\hline $\begin{array}{l}\text { Congress of } \\
\text { Democrats }(\mathrm{CoD})\end{array}$ & 5 & 0 & 32 \\
\hline DTA & 4 & 2 & 31 \\
\hline $\begin{array}{l}\text { Monitor Action } \\
\text { Group (MAG) }\end{array}$ & 1 & * & * \\
\hline $\begin{array}{l}\text { Namibia Democratic } \\
\text { Movement for Change } \\
\text { (NDMC) }\end{array}$ & 0 & 0 & 2 \\
\hline $\begin{array}{l}\text { National Unity } \\
\text { Democratic Organisation } \\
\text { (NUDO) }\end{array}$ & 3 & 3 & 9 \\
\hline Republican Party (RP) & 1 & 0 & 7 \\
\hline $\begin{array}{l}\text { South West African } \\
\text { National Union (SWANU) }\end{array}$ & 0 & 1 & * \\
\hline SWAPO & 55 & 96 & 168 \\
\hline $\begin{array}{l}\text { United Democratic Front } \\
\text { of Namibia (UDF) }\end{array}$ & 3 & 5 & 25 \\
\hline Local associations & * & * & 7 \\
\hline Total & 72 & 107 & 281 \\
\hline
\end{tabular}

Sources: ECN 2004,P14; The NAmibian 23 Nov 2004; New ERA 3 Dec 2004; New ERA 14 Dec 2004

* INDICATES THAT THESE PARTIES DiD NOT PARTICIPATE IN THAT PARTICUlar ELECTION 
The major issues of focus during the 2004 election were economic growth, poverty, unemployment, land reform, agriculture, infrastructure, the eradication of corruption, education, health care, social welfare, gender equality, good governance, moral values and HIV/AIDS. NUDO considered instituting a government of national unity, while MAG had no interest in forming a government. However, most political parties did not summarise and articulate the issues clearly enough to make them easily understood across the spectrum of voters.

The most notable aspect of the election manifestos is that there were no significant differences between the ideology and policy issues presented by the majority of parties, so voters were presented with limited choices. Opposition parties failed to present realistic alternative approaches to policy issues under consideration. There are some interesting (if not amusing) slight differences in some party manifestos. For example, the RP did not do its homework before writing its manifesto because it contains at least two factual errors (about abortion and samesex relationships) and the DTA wanted to utilise the environment to the fullest, while applying environmentally friendly conservation. Several other parties based their manifestos on ideologies such as socialism (SWANU) or religion (RP and MAG). Otherwise, the voters had little to go on when choosing between parties. This view is supported by Keulder and Soiri's (2004, p 47) survey of the 2004 local authority election candidates which showed minimal differences between the views of party candidates.

In the absence of viable policy alternatives, ethnicity, liberation struggle credentials and individual personalities within and between parties play a role in voting decisions. Most notably, voters often vote in what Keulder (2004, slide 30) terms ritual partisans (where voters vote for a particular party out of habit) and cognitive partisans (where voters vote for the same party out of choice, but with a high awareness of what they are doing and why).

As voters become more educated and exposed to global trends and as a new generation of voters grows up, its members born after independence and thus with no affinity to struggle credentials, they will begin to demand that parties provide more sophisticated platforms. If current parties do not provide meaningful manifestos the way could be open for new parties to lure away voters, leaving older parties having to entrench their hold on power through non-democratic means (as has occurred in Zimbabwe, for example). Eventually parties have to mature or they will lose their voter base (as with the $\mathrm{CoD}$, which is non-ethnic based) or they have to have some other method of consolidating power (as with Mugabe in Zimbabwe).

What emerges from the 2004 regional council elections is a hint of sustained ethnic voting patterns, with SWAPO's decisive wins in the Oshiwambo-speaking northern regions and an extension of its influence to the Kavango and Caprivi regions. (SWAPO's influence in Kavango and Caprivi might be due to the absence of other strong contending ethnic political formations in these two regions.) Both NUDO and SWANU won in traditional Otjiherero-speaking areas and the UDF 
won in its home of traditionally Damara-speaking areas. The parties without an ethnic constituency - or 'national parties' (such as the $\mathrm{CoD}$ ) - failed to win any seat in the regional council elections; the assertion that voters take an ethnic view when selecting which party to vote for therefore seems reasonable.

\section{Voter TURNOUT}

Table 2 shows voter turnout since independence. In the 1994 National Assembly and presidential elections, voter turnout was still high: 76 per cent (497 508) of the 654189 registered voters cast their ballots in the presidential and National Assembly elections, but with 1 per cent $(7863)$ of National Assembly votes and 2 per cent (12 213) of presidential votes spoilt (Hopwood 2004, p 38). However, the accuracy of the voters' roll and the system of tendered balloting were questioned when some northern constituencies recorded more than 100 per cent turnout.

Although the DTA challenged the results in the respective constituencies in court, the case 'fizzled' out some months after the election. Two opposition parties, the $\mathrm{CoD}$ and the RP, challenged the validity of the 2004 National Assembly elections. The court found that the voting process was upheld but that there were sufficient irregularities to order a recount of votes cast. However, this recount did not change the status quo, given the large margin by which SWAPO won. The implication here is that there is increasing voter apathy as a result of a loss of confidence in the integrity of the ECN to conduct free and fair elections. Even if more civic and voter education is done, a loss of faith in the system would have a negative impact on democracy building in Namibia. For example, Table 2 shows that voter turnout in the 1999 National Assembly and presidential elections declined to 61 per cent of registered voters, despite a lively election campaign.

In 1992 Namibia organised its first regional council and local authority elections, which took place simultaneously in the 13 regions and 48 local authorities. A new voters' roll contained 534437 registered voters and a turnout in excess of 80 per cent was recorded in both ballots (Hopwood 2004, pp 34-35). The ECN reports that regional and local elections have been hardest hit by voter apathy, especially in the urban areas (ECN 2004, p 12). There was a sizeable drop in voter turnout in the second regional council and local authority elections in 1998, with 40 per cent turnout for the regional elections out of 534278 registered voters (excluding uncontested seats), and 34 per cent for the local elections out of a possible 188302 registered voters (Hopwood 2004, p 38). The drop in voter turnout was ascribed to various causes such as lack of party mobilisation for support, voter dissatisfaction with the parties on offer, registration card confusion and people failing to register after moving to new towns (Hopwood 2004, p 35). This low voter turnout did not stop SWAPO from dominating the election, winning almost 60 per cent of the vote in the local authority elections and 69 per cent in the regional council elections. However, residents' associations gained control of Rehoboth and Otavi (Hopwood 2004, p 35). 
The 2004 local authority elections were organised separately from the regional council elections and took place in May, while the regional council elections were held on 29 and 30 November, after the National Assembly and presidential polls. Only 45 per cent of the 359152 registered voters (excluding those in uncontested areas) voted (Hopwood 2004, p 38). Voter apathy persisted even after the ECN voter education programmes for 2003, although the turnout was slightly higher

Table 2

Voter turnout at elections from 1989 to 2004

\begin{tabular}{|c|c|c|c|}
\hline Year & Registered voters & Votes cast & Turnout $\% *$ \\
\hline \multicolumn{4}{|c|}{ National Assembly $^{* *}$} \\
\hline 1989 & 701483 & 680787 & 97 \\
\hline 1994 & 654189 & 497508 & 76 \\
\hline 1999 & 879222 & 541114 & 61 \\
\hline 2004 & 977742 & 829269 & 85 \\
\hline \multicolumn{4}{|c|}{ Presidential } \\
\hline 1994 & 654189 & 497508 & 76 \\
\hline 1999 & 879222 & 545465 & 61 \\
\hline 2004 & 977742 & 833165 & 85 \\
\hline \multicolumn{4}{|c|}{ Regional Council } \\
\hline 1992 & $470006^{* * *}$ & 381041 & 81 \\
\hline 1998 & 534278 & 213789 & 40 \\
\hline 2004 & 977742 & 523746 & 54 \\
\hline \multicolumn{4}{|c|}{ Local Authority } \\
\hline 1992 & 156663 & 128973 & 82 \\
\hline 1998 & 188302 & 63545 & 34 \\
\hline 2004 & 363548 & 163999 & 45 \\
\hline
\end{tabular}

SourCe: Hopwood 2004, p 38; ECN 2004, p 11; 3 DeC 2004; NEW ERA 14 DeC 2004.

* Voter turnout is calculated here as a percentage of those people who registered to vote. This figure is slightly deceptive because there is a percentage of people who were eligible to vote but who did not register. Thus a more accurate reflection of voter turnout would be to calculate the percentage of people who voted against the total number of people who were eligible to vote. This method would yield a smaller voter turnout percentage but would more accurately reflect the percentage of Namibian citizens who voted. However, these figures were not available to the author.

** The 'National Assembly' votes of 1989 were in fact the Constitutional Assembly.

*** Excludes registered voters in uncontested constituencies and local authorities. 
than that of the 1998 local authority elections when only 34 per cent of registered voters cast their votes (ECN 2004, p 12; Hopwood 2004, p 38). Although there was a national average voter turnout of 45 per cent for the 2004 local authority elections, voter apathy was more notable in larger urban local authorities (ECN 2004, p 12).

The new voters' roll used for the 2004 National Assembly and presidential elections recorded 977742 registered voters. The results indicate an improvement in voter turnout for the presidential elections. A total of 833165 votes $(85 \%)$ was cast, with 14770 spoilt ballots, leaving 818395 valid votes. A recount also showed an 85 per cent voter turnout, with 829269 votes cast, 10830 spoilt papers and 818439 valid votes. ${ }^{4}$ However, the delay in counting and announcing the results of the National Assembly and presidential polls caused concerns about fairness and called into question the abilities of election officials and the quality of their training (The Namibian 18 November 2004). Voter turnout for the 2004 regional council elections was 53,5 per cent, an increase of 13,5 per cent over that in 1998.

In line with international trends, the most recent figures on voter turnout show that turnouts for local authority and regional council elections are lower than for National Assembly and presidential elections. This apathy is disconcerting, given that most Namibians have only had the vote for 15 years. In 2004, the local authority elections were held in May, while the regional council elections were held in late November, only after the National Assembly and presidential elections.

There are various theories about why there is a lower level of voter turnout for elections for lower levels of government. One of these is that because the regional council elections were held after the national elections voters may have believed that their job was done and therefore felt no obligation to vote in the regional elections; although this theory would not hold for the local authority elections, which were held first. However, the answer may be found in the perception that national and presidential elections are more important than regional and local elections. Regional councils are largely undefined and local authorities are seen as not wielding any power. Interviews with community members also show that some communities have experienced less development and thus people do not see the need to vote because they feel it will have no effect on development. Other community members believe that polling stations are too far away or that they do not have time to go back to their home constituencies to vote. Some people also explain that elections are sometimes held at month-end (which is when the majority of Namibians get paid); this means that people have other tasks to attend to and thus do not have time to vote (New Era 3/12/04).

4 Spoilt ballots may indicate one of three situations: first, that voters deliberately miscast their votes as a protest; second, a lack of voter education with voters spoiling papers because they do not know how to vote; and third, that electoral administration errors result in papers being declared spoilt. Given the higher than usual number ofspoilt ballots in the 2004 national elections, it could be argued lack of education cannot be the reason because the previous number of spoilt ballots was less than half the 2004 figure. Therefore, papers were either deliberately spoilt or there was some form of administrative error. Further analysis of the spoilt ballots would be required to determine the exact causes of the high number in 2004 . 


\section{Conflict AND Elections}

In any given society conflict surrounds power and political decision-making. Democracy, by its very nature, entails a certain level of development built through conflict. In recent years conflict surrounding the democratic process has not been confined to African countries, the controversy surrounding the American elections both in 2000 and 2004 illustrates the competitive nature of democracy: as well it should, for competition creates the opportunity for governments to improve service provision in an effort to maintain their voter base. Namibia witnessed its share of competition and conflict around the 2004 local, regional and national elections. Indeed, with the 2004 elections being the first to be held with a newly proposed presidential candidate from the ruling SWAPO Party, this election was the liveliest since independence.

\section{CONFLict AND THE Electoral SYSTEM}

There are still some contested domains within the electoral system itself which make some political analysts believe that it might be time for a change in the system. One long and considerably drawn-out dispute is the use of party lists which advantage older, more established party members while holding back disadvantaged groups (such as women and the disabled) as well as making it more difficult for younger politicians to move up the political ladder, or to advance other than through the 'grace' of older, entrenched party members.

One of the longstanding areas of contention is the party list system whereby parties put forward their list of candidates for the National Assembly and local authority elections and candidates are selected from these lists and ranked by their parties. Among the shortcomings of the list system is the fact that the lists are arranged by strong political officials; that candidates are loyal to their party rather than to their constituency and that lists give too much power to senior members of a party, entrench those already in power and can be used as a system of reward and punishment for those who do not toe the party line (Hopwood 2004, p 31). However, it has also been argued that the list system is preferable because the number of seats a party wins is a direct reflection of the number of votes it receives and that the list system is a simple, straightforward election method for voters who only have to choose their political party

Table 3 shows how National Assembly seats were allocated after the 2004 election recount. First the total number of valid votes (818 439) was divided by the number of National Assembly seats (72) so for every 11367 votes a party received, it won one seat. This meant that 67 seats were allocated. The remaining five seats went to the five political parties with the largest number of unallocated votes (the 'largest remainder'). Thus, although the MAG did not have enough votes to win a seat it was awarded one because it had the fourth largest number of unallocated votes. 
Table 3

Allocation of NA seats using PR and 'Largest Remainder' Method

\begin{tabular}{|l|c|c|c|c|c|}
\hline Party & $\begin{array}{c}\text { Total } \\
\text { NA Votes }\end{array}$ & $\begin{array}{c}\text { Seats for } \\
\text { every } \mathbf{1 1 3 6 7} \\
\text { votes }\end{array}$ & $\begin{array}{c}\text { Votes not } \\
\text { allocated } \\
\text { to a seat }\end{array}$ & $\begin{array}{c}\text { Seats to 5 } \\
\text { parties with } \\
\text { largest } \\
\text { remainder }\end{array}$ & $\begin{array}{c}\text { Total } \\
\text { no of } \\
\text { seats }\end{array}$ \\
\hline CoD & 59464 & 5 & 2629 & - & 5 \\
\hline DTA & 42070 & 3 & 7969 & 1 & 4 \\
\hline MAG & 6950 & 0 & 6950 & 1 & 1 \\
\hline NDMC & 4380 & 0 & 4380 & - & 0 \\
\hline NUDO & 34814 & 3 & 713 & - & 3 \\
\hline RP & 16187 & 1 & 4820 & - & 1 \\
\hline SWANU & 3610 & 0 & 3610 & - & 0 \\
\hline SWAPO & 620609 & 54 & 6791 & 1 & 55 \\
\hline UDF & 30355 & 2 & 7621 & 1 & 3 \\
\hline Total Valid Votes & 818439 & 68 & - & 4 & 72 \\
\hline
\end{tabular}

Source: NeW ERA 17 March 2005; The Namibian 17 March 2005

The PR system as it is practised in Namibia has several shortcomings. These include the fact that it encourages small political parties and favouritism because even small parties without a substantial constituency base may win a seat in the National Assembly, and personalities wishing to sit in the National Assembly can break away from political parties, form their own party and stand a chance of winning a seat (LeBeau and lipinge 2004, p 80). In fact, the government funds political parties according to the number of seats they have in Parliament. Thus, once a small party has a seat, it is able to advance itself through government funding. This is true because, unlike many other countries, Namibia does not have a legal 'threshold' (suggested as 5\%) for representation whereby parties must have a minimum level of support in order to have a seat in Parliament. Indeed, the threshold is lower for parties at National Assembly level (1,39\% of votes) because of the number of seats (72) available (Keulder 2004). This lack of a legal threshold may be seen to encourage ethnic differentiation in political parties because parties need a voter base of only a few thousand people - and thus only seek support from their core base rather than attracting members outside of their core area of support (Hopwood 2004, p 29). The result is that the PR system discourages true multiparty competition in addressing policy-based issues because parties can rely on their ethnic base.

In rewarding small parties the system also discourages alliances of smaller parties to form larger coalitions, which might become an effective opposition to 
the majority party, SWAPO. In addition, the Namibian PR system leads to fewer women in the National Assembly because the leaders of the political parties are men and small parties that are awarded only one seat or win only a few seats are unlikely to appoint a woman to those seats.

Although Namibia has made significant strides in formal legal reforms in the area of gender equality, much of this progress has not translated into action when it comes to women in the democratic process. One area where law reform has been proposed but not accepted is the 50/50 campaign and its resultant 50/50 Bill, which has been presented before Parliament. The 50/50 campaign in Namibia began in 1999 , but is a global effort aimed at achieving gender equality in political representation. The campaign advocates 'zebra'-style lists which alternate women and men candidates for all elections so that half the candidates put forward are women (Namibian Women's Manifesto Network 2003).

The Women's Manifesto, developed in 1999-2000 in collaboration with stakeholders, created the Namibian Women's Manifesto Network which identified amendments to the Namibian electoral Acts (currently referred to as the 50/50 Bill) that were supposed to ensure a gender balance in political power structures (Khaxas and Frank 2003, pp 5-6). The 50/50 Bill went before Parliament and was referred to a standing committee for review. Despite intense lobbying and popular support from non-governmental organisations (NGOs) and women's groups in Namibia, the standing committee rejected the Bill and ruled that a procedural mistake had been made because all other avenues for submission of a Bill had not been exhausted. Some women's organisations argue that the government is not being held accountable to women because government officials are accountable to their political parties and not to their constituents (Khaxas and Frank 2003).

\section{Conflict within Political Parties}

Two significant conflicts that arose within political parties in the run-up to the 2004 elections centred on power sharing within the parties: the first was related to SWAPO's selection of a new candidate for president, the other resulted in a split within the DTA. Although such inter-party reorganisation is not new to politics, the flurry of attention and the results - especially for the DTA, which lost considerable power - will shape the Namibian political landscape for years to come.

Probably the most publicised conflict occurred within SWAPO and concerned the selection of a successor to President Sam Nujoma, who had announced that he would not run for an additional term. In April 2004, SWAPO's Central Committee met and three names were put forward as candidates for the party's presidential nominations: Hidipo Hamutenya, the Minister of Foreign Affairs; Nahas Angula, the Minister of Higher Education, Training and Employment Creation and Hifikepunye Pohamba, the Minister of Lands, Resettlement and Rehabilitation. Delegates to SWAPO's Extraordinary Congress were to choose which of the nominees would run for the party in Namibia's next presidential race. 
Until the SWAPO Party Congress late May, each candidate and his supporters lobbied quietly in an effort to sway party members to support his bid for the presidency (Sherbourne 2004). Minister Pohamba was favoured by the President and was considered to be the closest in political outlook to Nujoma and the candidate least likely to effect changes. Minister Angula enjoyed support among younger, more educated members while Hamutenya - although not backed by the President - enjoyed a large following among many top SWAPO officials. However, the President dismissed Hamutenya as Minister for Foreign Affairs (as well as Hamutenya's deputy minister) four days before the congress (Sherbourne 2004, p123). Hamutenya, however, refused to step down as a candidate. In the first round of voting he came second to Pohamba, but with no clear majority. A run-off vote saw Angula step down and throw his backing behind Pohamba, who won 341 votes to Hamutenya's 167 (Sherbourne 2004, p123).

This conflict continued for some time: several Hamutenya supporters have lost their jobs or other positions since the congress, giving rise to allegations that they are being targeted. At a SWAPO Party meeting in October 2004 to elect the party's National Assembly candidates, a list containing the names of 35 people who had supported Hamutenya's bid for the presidency was circulated. The President said the list was not sanctioned and was the work of 'reactionaries' who wanted to divide the party. Regardless of the origins of the list, most of those on it lost votes for the National Assembly party list and thus were not in positions to win seats in the National Assembly (The Namibian 8 December 2004). Events after the SWAPO Party extraordinary congress are seen as originating from tribalism and disunity in the party's ranks, an example of what has been termed 'ethnic entrepreneurs at work in a hegemonic formation' - meaning that an ethnic voter base tends to keep the politics of race alive, therefore ethnic-based political parties are not healthy for democracy building in the country (du Pisani in The Namibian 18 February 2005).

Major conflicts have also been rife within the Democratic Turnhalle Alliance for some time..$^{5}$ In 1998 the DTA ousted its president, who was suspected of plotting a coup in the Caprivi region and subsequently many Caprivi region DTA supporters stopped voting or turned to SWAPO (Hopwood 2004, p 49). A further blow to the DTA support base came when the party's administrative secretary resigned. The final blow occurred in 2003 when NUDO and RP party members spilt from the DTA alliance. The centre of contention seems to have been in the RP, which claimed that the DTA had not promoted national reconciliation and that it now lacked credibility with voters; while NUDO members claimed that the DTA had been 'riding' on the Herero vote (Hopwood 2004, p 49). The viability of the DTA, RP and NUDO are now in question.

5 The DTA was formed in 1977 as an alliance of 11 ethnically-based parties, including NUDO and the RP, which had walked out of the Turnhalle constitutional talks over the demand of the National Party to retain some apartheid legislation (Hopwood 2004, p 46). 
Within the DTA there are also sites of contention, with some former NUDO members claiming that Chief Riruako did not have the legal right to split from the DTA and call the party NUDO. The DTA took NUDO to court, but NUDO won and was allowed to register and take part in the elections. Such splits bolster the contention that the PR system encourages small political parties, especially where voters are used to voting along ethnic lines, when a spilt based on policies and programmes could be more beneficial to Namibian citizens. Indeed, the DTA made an exceptionally poor showing in the 2004 elections, losing seats in all areas: in the local authority elections it lost 14 of its 16 seats; in the National Assembly it dropped from seven to four seats and it only won two seats in the regional councils. Of the two parties that spilt from the DTA, NUDO was the more successful, out-performing the DTA in some elections. This means that the DTA has now lost its status as the official opposition party and may even be set to lose further ground in subsequent elections (New Era 8 December 2004).

\section{Conflict between Political Parties}

In the run-up to the 2004 elections and the post-election manoeuvring, a few points of contention arose between political parties. In general these issues related to opposition parties confusing the government with the ruling SWAPO Party. When irregularities occurred within the process, parties tended to attribute these to SWAPO rather than to government officials.

During the campaign phase of the election there were instances of party members deliberately interfering with other political party rallies, sometimes with violence erupting. For example, at a CoD rally held in Swakopmund, SWAPO supporters were accused of holding their own rally within 500 metres, which is the specified limit parties are supposed to respect when other parties hold rallies. This incident resulted in physical confrontations between party members.

In another incident, after the National Assembly and presidential elections valid, filled-in ballots were 'discovered' dumped on the roadside under the Swakop River Bridge near Okahandja. Although the ECN (as a branch of government) was in charge of the elections and thus was ultimately responsible for this possible irregularity, some opposition parties accused SWAPO of having orchestrated the disposal of opposition votes. On 3 December 2004 SWAPO took out a full-page advertisement in the New Era (and published one in its own newspaper, Namibia Today) defending itself against these accusations. The advertisement stated that there was no proof linking SWAPO to ballot dumping and that SWAPO was not affiliated with the ECN and thus could not have been responsible for any election irregularities that might have occurred.

Despite months of discussion, media reports, accusations (and counteraccusations) as well as a police investigation the matter has yet to be resolved. The ECN alleges it has evidence that opposition party members planted the ballots in an effort to discredit the election results, while opposition party members claim 
that the ECN manufactured the allegation to defend itself against a pending court case requesting that there be an external audit of the results or that the results be set aside and new election take place - the investigation is still underway.

\section{Conflict Surrounding Elections}

Even before the voting was over some critics predicted a low voter turnout or that the fragmentation of the DTA would lead to a fragmentation of votes between opposition parties as well (The Namibian 15 November 2004). Although the vast majority of election-related complaints centred on the mechanics of voting and the $\mathrm{ECN}$, there were one or two instances where individual candidates were accused of attempting to influence election outcomes. One such example came from the Caprivi region where the National Society for Human Rights (NSHR) witnessed a candidate for the regional council handing out money to party agents, police officials and election officials (The Namibian 18 November 2004). The candidate concerned was elected to the regional council. An NSHR election observer also reported a 'dancing and drinking' party going on at one polling station in this area while voting was still taking place.

In the wake of the national elections there have been accusations about problems with ballot counting as well as other irregularities, particularly aimed at the ECN. The core of most of these complaints has been the fact that the ECN, although an independent body, is run by government, which is dominated by SWAPO, with opposition parties claiming that there is no provision for them to audit voting outcomes (The Namibian 18 November 2004). However, the Electoral Act of 1992 clearly stipulates conditions under which political party members can register with the ECN to observe the vote count, and the count for the 2004 national elections was witnessed by political parties and foreign observers.

Probably one of the more glaring problems that caused the ECN to come under fire from opposition parties is the fact that it took far longer to count the national election ballots than projected, causing some opposition party members - as well as members of the public -to question the counting procedure. As party members nervously awaited the results the ECN postponed the deadline for the release of the first results. One reported cause of the delay was the tendered ballot system which allowed voters to vote at any polling station, not merely the area in which they lived. One ECN official explained that because ballots were not necessarly cast in the voter's own constituency, all the ballots had to be sorted and each had to be allocated to its constituency (Kuteeue for Reuters 18 November 2004).

Some accusations of irregularities centred on procedures that had not been followed at polling stations; for example, that infrared lights were not used to detect the ink marks identifying a person as having voted, or that some people were able to wash the ink off their hands and thus vote again (New Era 8 December 2004). ECN officials said they would address this problem in future by marking two fingers in a place that was more readily visible and where it would be more difficult to 
wash the ink off (New Era 26 November 2004). The ECN's response to accusations of ballot boxes being stuffed with extra ballots was that this was not possible because there had been government security officials at all polling stations (The Namibian 18 November 2004). Other, although infrequent, problems raised were claims of intimidation and claims that people had been told for whom they should vote (New Era 8 December 2004). A further point of contention was the fact that 1,8 million ballots were printed for only 977742 registered voters. Questions were raised as to why so many ballots had been printed and what had happened to the unused ballot papers (The Namibian 18 November 2004).

After the National Assembly and presidential election results had been released, some opposition parties questioned how in some constituencies (even the smaller ones) more voters turned out than were registered to vote. The ECN claimed that this inconsistency was caused by the tendered ballot system. Some opposition members also questioned the unusually high turnout rate for the national elections. However, the ECN said it viewed the high voter turnout as a positive, not negative attribute of the elections because it showed that there was no political apathy in Namibia (The Namibian 18 November 2004).

Concerns have also been expressed about the number of spoilt ballots (11 405) in both the presidential and National Assembly elections. In the 1999 presidential and National Assembly elections only about 1 per cent of papers were spoilt (6 617 and 5078 respectively) (The Namibian 8 December 2004). In the local authority elections, too, there was an increase (of 50\%) in spoilt ballots in 2004 compared to 1998 (Hopwood 2004, pp 38-39).

Controversy continued to surround the 2004 National Assembly and presidential election returns when the ECN announced it had made a mistake in rejecting ballot papers as spoilt because they did not carry the prescribed 'secret mark or stamp'. The ECN required each election official to place this secret mark on voters' ballots, but after a higher than expected number of ballots were rejected for not having the mark, an internal investigation was ordered, whereupon it was discovered that some election officials had failed to use the prescribed stamp. This led the ECN to conclude that about half of the 11405 votes that had been declared invalid were, in fact, valid. The Director of Elections admitted to 'human error' and said that the officials in question would be demoted. He added, however, that he did not suspect foul play (The Namibian 8 December 2004). Opposition parties reacted negatively to the news of the spoilt ballots, with the RP saying it reflected 'inefficiency' on the part of the ECN for not having trained staff properly or provided enough voter education. The ECN retorted by reminding political parties that they too bore responsibility for educating voters.

Several members of opposition parties were not satisfied with the voting process and some parties contested the 2004 presidential and National Assembly election results and lodged an application with the courts to have the count verified by an independent auditing body (New Era 25 November 2004; The Namibian 8 December 2004). Representatives from the CoD and the RP said that, given several 
irregularities in the voting process and queries about the post-voting procedures, they wanted the voters' roll, tender ballots, spoilt ballots and ballot books reexamined (New Era 25 November 2004). Opposition parties were granted a High Court order allowing them to inspect the ECN election documents. When this was done several irregularities were discovered (New Era 14 December 2004).

However, even though opposition party members were able to show irregularities in the voting procedures, if they were to win their bid to have the National Assembly elections set aside they would have had to show that these irregularities were of such magnitude that they affected the election results and even then all the court could do would be to order a full external audit of the outcome or a ballot recount. As it turned out, in mid-March 2005 the court found that there had not been sufficient irregularities in the election process itself to warrant the outcome being set aside but that there had been enough irregularities in the counting process for it to order the ECN (not an external body) to recount the votes.

The recount differed only slightly from the original count (818 439 versus 813 955). SWAPO lost 178 votes and the CoD lost one while the DTA gained 356, the MAG 30, the NDMC 242, NUDO 940, the RP 222, SWANU 172 and the UDF 1019. The most contentious issue of the recount was that the 935 votes from the Ohangwena region were damaged by rain, thus preventing them from being recounted (New Era 17 March 2005; Namibian 17 March 2005).

\section{Interpersonal Politically Related Conflict}

Although there were some alleged instances of political parties inciting their members to violence against opposition party members, probably the most common form of political violence occurred when members of opposing parties got carried away with election fever and attacked each other. For example, a report from the Kavango Region on 18 November claimed that a SWAPO supporter hit a CoD candidate during a SWAPO political march. The police reported that marchers shouted 'down with $\mathrm{CoD}^{\prime}$ ' as they marched past the CoD candidate's shop and the candidate responded, which led to the $\mathrm{CoD}$ candidate being hit on the head. SWAPO, it was reported, was sending a regional coordinator to investigate the incident (The Namibian 18 November 2004). The CoD believed this was a political attack on the party's candidate, while SWAPO maintained that the CoD candidate had provoked the SWAPO Party members. Although this was only an isolated incident of interpersonal violence possibly motivated by political affiliation, it does serve to show that political parties did not orchestrate the attacks.

\section{REPRESENTATION OF WOMEN}

One area where it was hoped that there might be a shift was that of greater women's representation at the various levels of political decision-making. However, this was not the case after the 2004 elections. Although there has been a slight increase in the 
number of women in some decision-making bodies, the proportion is far below the 30 per cent that Namibia agreed to when it signed the SADC Declaration on Gender and Development. Although women scored an early victory, with 43,4 per cent representation at local levels of government, they did not fare so well in the National Assembly and regional council elections. The local election results were achieved largely by affirmative action measures to promote women, which require political parties to place a given number of women on their lists.

In the end, women's representation increased by less than 1 per cent - from 26,4 per cent to 27,3 per cent (The Namibian 24 November 2004). In the National Assembly, 27,3 per cent of SWAPO representatives are women, 40 per cent of the $\mathrm{CoD}$ and 33 per cent of the UDF, while the DTA, NUDO, MAG and the RP have no women representatives (The Namibian 24 November 2004). The low level of representation of women at national level stems from the fact that although all the political parties had more than 30 per cent women candidates on their lists, the women's names were placed too far down for them to get seats in the National Assembly (New Era 25 November 2004). As mentioned above, women's low representation in the National Assembly can be attributed partly to the type of political systems used in Namibia to decide who sits in the National Assembly. For instance, the system of 'largest remainder' results in small political parties that are likely to win only a few seats tending to place men in the winning positions on their lists. As the above figures indicate the only three of the seven parties represented in the National Assembly who have women representatives are among those which won the most overall seats. The only exception is the DTA, in which women have consistently been under represented.

In 2004107 regional councillors were elected. In 6 of the 13 regions there are no women councillors and only three $(23,1 \%)$ women have been appointed regional governors. Women's representation in the National Council increased from 7,7 per cent in 1998 to 26,9 per cent in 2005. However, the deputy chairperson of the National Council (a woman), who was in line to take over as chairperson of the House, was passed over in favour of another member (a man). It had been hoped that the deputy chairperson would have become the first woman chairperson of the National Council (The Namibian 13 December 2004). Although the regional councils are sending more women to the National Council, women are still seriously under-represented at regional level. Given that in all cases political parties either nominate candidates for election or put them on party lists, this poor showing rests squarely with the decision-making wings of political parties (The Namibian 24 November 2004).

\section{Democratic Consolidation in NAmibia}

This paper has examined various democratic processes and the consolidation of democracy in Namibia with specific reference to the most recent elections. The data indicate that Namibia is on its way to being a strong democracy, although the 
democratic process in the country faces challenges that could threaten the consolidation of democracy. Given that Namibia has been independent for only 15 years, democracy is in its infancy and needs to be nurtured lest it fall victim to alternative forms of government such as dictatorship or military rule. Some of the more formidable challenges facing the democratic process in Namibia are discussed below.

\section{The Need to Support the Consolidation of Democracy}

There are some 'products', even in a capitalist economic system, which cannot be independently economically sustainable. Many of these, such as law reform, advancing minority rights (eg, women or the disabled) and support for the democratic process relate to the 'public good'. Many 'products' have a price which people are willing to pay, but how much would - or could - each citizen contribute to, for example, civic and voter education or to the printing of ballot papers? Without support most aspects of the democratic process such as political parties and voter education would not be available and thus there would be no democracy. The government, NGOs, and donors put substantial human and economic resources into the implementation of the election process. This expenditure of human and economic capital is necessary given that democracy can best be viewed as a 'common good' (or common product) that is owned by none, but shared by all. Therefore, it is the responsibility of government, as well as civil society, to protect and encourage this 'common good'. It is only through the efforts of those such as the ESC, the government, bilateral donors and civil society that democracy can be said to be consolidated in Namibia.

\section{Issues Around the 2004 EleCtions}

The run-up to and preparations for the 2004 elections in Namibia witnessed conflict at various levels. Pre-election conflict centred on issues of obtaining greater women's representation, the possible bias of the media and, importantly for this election, conflict within political parties. The majority of physical and interpersonal violence tended to stem from over-exuberant party supporters; while political mud slinging came from parties dissatisfied with the election results.

The most recent elections have seen a realignment of political personalities both within and between political parties. The split of two factions from the DTA (the RP and NUDO) has created more divisions, leading to SWAPO's consolidation of power in several regions and sectors: this fracture split votes for the DTA, resulting in its losing to the $\mathrm{CoD}$ its status as the official opposition.

Another disconcerting issue in Namibian politics is the tendency of SWAPO to deal harshly with internal dissent even when the competition was originally sanctioned within party structures. Although the question within the party of who was to be its presidential candidate was resolved (and indeed the SWAPO 
presidential candidate has been elected as the next Namibian president), the fallout of the conflict surrounding the nomination at the party's congress continues to be felt even after the elections. Several SWAPO stalwarts have resigned, lost their positions or been demoted - with widespread speculation that these actions have been taken against Hamutenya supporters as a result of the candidacy nominations.

\section{Attitudes To Democracy}

Recent research has found that there is a growing tendency for people to be disenchanted with the form of democracy in Namibia, a trend discernible in the extent of voter apathy. Research has shown that more people are beginning to believe that alternatives to democratic rule might be acceptable or that the multiparty system does not function well. Some of this disillusionment is a result of the country's slower than anticipated economic and social progress. Some of this slow pace of development can be attributed to an unfortunate twist of historical fate - Namibia became independent at the same time that AIDS was tightening its grip on the Southern African region and Namibia's independence allowed for the free movements of people within and between countries, exacerbating the spread of HIV infections.

Given the challenges facing a new country that has risen from the ashes of more than 100 years of colonial rule, the additional burden of the AIDS pandemic has seriously impinged upon government's development efforts. Several parties have used the social and economic challenges still facing Namibia as a basis on which to formulate their platforms; however, most political parties not only fail to offer implementable alternatives to the ruling SWAPO Party policies and programmes, they fail to identify mechanisms to fund their proposed policies. Despite these issues, however, people generally still have an overall positive feeling about Namibian democracy, although this is beginning to change.

\section{Do all Democrats Want Democracy?}

Many democratic countries assume that what everyone else in the world wants is more democracy. Often democrats are so busy trying to promote democracy by converting non-democratic countries and reinforcing democratic principles in countries that already have democracy that they fail to ask if this is really what everyone wants. Indeed, Western style democrats are so fundamentally opposed to Marxism, socialism and communism that they forget that their style of democracy might, firstly, not be the only option, and secondly, not be the choice of other people in other forms of democratic processes. There is a growing trend for Western democrats to become frustrated and want to attack as undemocratic non-Western style democracies, while not acknowledging other possible forms of governance (which do not have to be undemocratic just because they are un-Western). Indeed, the Greeks did not have a 'true' form of democracy because women and slaves did 
not have the right to vote; and women's suffrage came to most Western countries only after the first half of the 19th century. This is not an argument for disenfranchising certain groups of people but an acknowledgment of the possibility that other people may not see Western democracy the same way Westerners do.

The research discussed above indicates that the attitudes and behaviours of the youth do not necessarily reflect a strong affinity with democracy, nor do the youth particularly participate in the democratic process. Are these trends peculiar to the youth or is this a general trend in Namibia? The most recent IPPR Afrobarometer data indicate a growing trend in Namibia to wonder whether democracy is right for the country. This 2003 research shows that the proportion of Namibians who said they preferred democracy had dropped from 57,3 per cent in 1999 to 54,4 per cent, while the percentage of people who believe that a non-democratic government might be preferable or that the type of government does not matter to them has steadily increased (Keulder 2004, slide 7). This data may not seem too disconcerting unless certain other facts are taken into account, such as the fact that these figures represent a drop of 3 per cent in three years, implying a 1 per cent drop a year, which is especially worrying in light of the fact that Namibia has been independent for only 15 years.

In fact, Keulder (2004, slide 8) found that the preference for all types of nondemocratic options has risen since 1999, with single-party rule and military rule leading the field in the 2003 data. Van Zyl and Keulder (2001, p 11) state that democracy cannot exist unless the majority of citizens prefer it to other forms of rule. They go on to explain that in newly established democracies the preference for democracy is neither uncontested nor consolidated and that democracy can only be considered consolidated when most of the citizens and the elite are committed to it and are of the opinion that democracy is always best (Van $\mathrm{Zyl}$ and Keulder 2001, p 12).

\section{Were the 2004 Elections Free And Fair?}

This paper has examined traditional views of political participation, as well as conflicts surrounding the 2004 electoral process.

Despite a number of problems with the democratic process and some electionrelated conflict, most political observers believe that the elections were not only free and fair, but that they should be held up as the benchmark for free and fair elections elsewhere in Africa (The Namibian 18 November 2004). Both EISA and the SADC Parliamentary Forum observer missions to Namibia observed that the National Assembly and presidential elections went peacefully and reasonably smoothly, with the head of the EISA team stating that the Namibian elections were some of the best he had witnessed, with everything going 'according to the rules of the game' (The Namibian 18 November 2004). Indeed, international election observers believe that election strategies for other Southern African countries should be based on the Namibian example. Many election monitors commented that they were 
accorded unhindered access to polling stations and vote counting halls, which they believed was crucial for transparency in the election process (The Namibian 18 November 2004). Although there have been accusations of intimidation and other poll irregularities, the missions to Namibia reported that they saw none of this at the polls they monitored. If such behaviour did occur, it was probably based on individual initiatives and not on some form of organised political intimidation.

Irrespective of the typical conflicts and complaints that accompany any election of national import, most political parties expressed satisfaction with the voting process (The Namibian 18 November 2004). One opposition member said that although he was frustrated by the lack of training received by some election officials, his party in principle endorsed the outcome of the National Assembly and presidential elections (New Era 26 November 2004). For its part, ECN representatives have also expressed their satisfaction with the voting process and stated that: 'All Namibians have once again proven to the rest of the world that elections can be held in an atmosphere of calmness, peace and tolerance' (Pretoria News 18 November 2004).

In 2004 the ECN succeeded in re-registering almost one million voters, conducting by-elections, administrating local, regional, national and presidential elections, as well as providing voter education at national and grassroots community levels. Given the massive task of re-registering almost one million voters, organising three rounds of voting and educating the general population on voter procedures, the ECN - with its associated support systems - has done an acceptable job of contributing to the democratic process. Of course, it did not achieve this alone: the democratic process in Namibia is a cooperative (and sometimes competitive) effort between government, donors, NGOs, civil society and political parties.

It is hoped that the ECN has learned from some of its mistakes, which contributed to the problems and irregularities described above, and that it will undertake to resolve these issues so the democratic process runs more smoothly and appears more professional.

The outcome of the court case in which some opposition parties alleged mass irregularities in the National Assembly elections and the resultant recount (conducted in only four days) speaks volumes for the health of Namibia's democratic process. The fact that opposition parties could challenge the election outcome (which it would be impossible to do in some countries) shows that in Namibia one can still question the democratic process. Furthermore, the similarity in results between the first count and the court-ordered recount indicates that, although problems were experienced, the ECN did succeed in its stated objective of holding creditable elections in 2004.

\section{The Future of Democracy in Namibia}

Probably one of the most significant contributions to the consolidation of democracy in Namibia is the ESC. Other contributors to the democratic process include bilateral 
donors, NGOs and civil society - many of which work directly on issues relating to democracy, while others strive to develop the social, economic and educational lives of Namibians, and thus also prepare the stage for a greater understanding of and participation in the democratic process. Educating and raising the social status of the general Namibian population, as well as exposure to globalising trends, will mean a more sophisticated Namibian electorate. This should push the consolidation of democracy in the country to an advanced level where policies and programmes influence the way people vote more than ethnicity, liberation credentials and charismatic personalities.

SWAPO is in conflict because of the fission between Pohamba and Hamutenya. One political option could be to appoint to the National Assembly some SWAPO Party members who have been alienated from the party over the presidential candidate race, thereby attempting to bridge the divide. If the party does not try to make some gesture towards this group of alienated party members, it could split, which would mean it would no longer be guaranteed such high rates of support in the future. It should be noted, however, that SWAPO Party officials say there is no tension within the party, only ill feeling; and if there are 'witch-hunts' these should be stopped because they will cause disunity in the party (New Era 13 December 2004). Indeed, SWAPO members have made several published statements stating that no party member should sow discontent within the party and that anyone doing so could face expulsion (the terms of which are laid out in the party's code of conduct). In what could be seen as a move by the outgoing president to quell dissatisfaction - from both inside and outside SWAPO ranks - the President has called on all Namibians to embrace national reconciliation and unity, stating that: 'Together we must build a truly united country, a prosperous Namibia in which the future generations will enjoy human dignity, equality and freedom.' (The Namibian 13 December 2004; New Era 13 December 2004).

Namibia still has serious political and ethnic divides, as well as a general lack of understanding and acceptance of democracy: these factors could be a potentially serious obstacle to democratic consolidation. However, there are also positive attributes such as high literacy rates, good levels of trust in representatives and a strong belief that the process is responsive to the needs of the people - all of which are conducive to the consolidation of democracy (Keulder 2002, p i). It seems that if it is to continue to consolidate democracy Namibia will have to face voter apathy, rising rates of tolerance for other forms of government, and plummeting voter confidence in the very democratic officials they have elected. Probably one of the best ways of consolidating democracy is through civic and voter education, which should not be viewed as being necessary only at election time but should be an ongoing process that reinforces citizens' as well as politicians' demands for democracy. 


\section{REFERENCES}

Du Pisani, A. 2005. 'Towards a vision of a just society'. The Namibian 18 February 2005.

ECN. 2004. Annual Report 2003-2004. Windhoek: ECN.

EISA. 2004. Principles for Election Management, Monitoring and Observation in the SADC Region. Electoral Handbook. Johannesburg: EISA.

ESC. nd. Voter education discussion paper. Windhoek: NID.

Government of the Republic of Namibia (GRN). 1990. The Constitution of the Republic of Namibia.

—. 1992. Electoral Act No 24 of 1992.

-. 2003. Electoral Amendment Act No 7 of 2003.

Hopwood, G. 2004. Guide to Namibian Politics. Windhoek: NID/IPPR.

Keulder, C. 2002. Perceptions of Human Rights and Rights-Related Issues among Namibian Youth: Results from Focus Group Discussions. Windhoek: IPPR/NID.

—. 2004. Afrobarometer, Namibia 2003. Windhoek: IPPR.

Keulder, C \& I Soiri. 2004. Local Authority Representation in Namibia: Results of the 2004 Representatives Survey. Windhoek: IPPR.

Khaxas, E \& L Frank. 2003. Promoting Women's Participation in Politics and Law Reform by Collectively Developing Specific Demands for Affirmative Action Legislation with regard to Elections at all Three Levels of Government. Windhoek: Sister Namibia. Kuteeue, P. 2004. 'Namibian election results delayed'. Reuters 18 November.

LeBeau, D \& E lipinge. 2004. 'Women and power-sharing: Namibia's progress towards gender equality'. In C Lansberg \& S Mackay (eds). Southern Africa Post-Apartheid?: The Search for Democratic Governance. Cape Town: Centre for Policy Studies (CPS).

Namibian, The. 2004. 'Politics - the business of the elders'; 'Where could Namibia be heading?: An analysis of the parties' manifestos', 15 November.

- 2004. Vote buying alleged in the Caprivi; Observers happy with poll, 18 November.

—. 2004. 'MPs for 2005-2010'; 'Swakopmund attack claimed to be "political"', 23 November.

—. 2004. 'Women main poll losers', 24 November.

—. 2004. 'Swapo sweeps the board: DTA loses 14 seats'; 'Another top Windhoek municipality official quits', 3 December.

—. 2004. 'ECN admits ballot errors'; New board for NamPower'; 'Angula resigns from cabinet', 8 December.

—. 2004. 'Women presence up in new $\mathrm{RC}^{\prime}, 9$ December.

—. 2004. 'SWAPO wields whip in regions'; President preaches unity', 13 December.

- 2005. 'ECN gives vote verdict', 17 March.

Namibian Women's Manifesto Network. 2003. 50-50: Women and men in Local Government - Get the Balance Right!. Pamphlet. Windhoek: Sister Namibia. 
New Era. 2004. 'Parties cry foul over candidates' gazetting'; 'Pohamba speaks on cabinet'; 'ECN can't wait for big day'; 'DTA youth have misgivings', 26 November.

—. 2004. 'Women overlooked'; 'Opposition to sue ECN', 25 November.

—. 2004. 'SWAPO Party press statement on the alleged dumped ballot papers at Okahandja'; 'The final tally, SWAPO sweeps the landscape'; 'Allegations of unfairness emerge'; ' "No development" blamed for voter apathy', 3 December.

—. 2004. 'Helmut Angula calls it a day'; 'Kaura fears losing constituencies'; 'SWAPO's Ojimbinde candidates cry Foul', 8 December.

—. 2004. 'Nujoma urges reconciliation'; 'Angula unhappy', 13 December.

—. 2004. 'Elections 2004: The final tally', 14 December.

—. 2005. 'SWAPO still winner', 17 March.

Pitkanen, P. 2004. Joint Civic and Voter Education and Voter Registration Programme in Namibia.Windhoek: ESC.

Pretoria News. 2004. 'Namibian elections viewed as successful', 18 November.

Sherbourne, R. 2004. After the Dust has Settled: Continuity or Stagnation? IPPR Opinion No 16. Windhoek: IPPR.

Somach, S, D LeBeau \& J Mindes. 2004. Gender Mainstreaming and Disability Sensitization in Civic and Voter Education in Namibia. Washington, DC: USAID.

Van Zyl, D \& C Keulder. 2001. Youth and Democracy in Namibia: Results of the Youth and Politics 2000/01 Survey. Windhoek: IPPR. 